\title{
Research on Financing of Chinese Textile Listed Companies
}

\author{
Xin-Ying Liu ${ }^{1, a}$, Wen-Wen Liü,b, \\ ${ }^{1,2}$ School of International Trade and Economics, Shandong University of Finance and Economics, \\ Jinan, China \\ asheila_guo1988@hotmail.com, bliuwenwen888999@163.com \\ ${ }^{*}$ Corresponding author
}

Keywords: Textile industry, Listed company, Financing, IPO.

\begin{abstract}
Textile industry is one of the pillar industries in China which plays an important role in developing national economy. China's textile industry companies, especially the textile listed companies, experienced a rapid development with the increase demand in both international and domestic markets, but in the meantime there are still some problems in the development of textile listed companies. To achieve further development, textile listed companies requires adequate financial support, but the financing situation of China's textile listed companies is not so optimistic. Textile listed companies takes a large proportion in all textile enterprises of China, so it is meaningful for the healthy development of China's textile industry analyzing the general financing situation of textile listed companies and proposing recommendations for the better development of the textile listed companies financing.
\end{abstract}

\section{Introduction}

Since the reform and opening up, China's textile industry has developed quickly, and it has formed the world's largest textile industry system having a complete industrial chain, which has an obvious comparative advantage in the world. It not only plays a major role in China's national economic accumulation, solving the employment, improving people's living standard, export industry and finishing industrial supporting, but it positively promotes to solve the three agricultural question and raise the level of urbanization. With the growing of domestic demand and the development of international market, the textile industry will still in rapid growth, and it will also face many problems like further adjusting structure and strengthening to foster innovation. All these need a large amount of fund, and the capital inflow can make the enterprise free of funds shortage. In a certain number of their own funds, they can expand the scale of production and create more wealth for the enterprise. As to the listed company, it is more important for the textile industry to get more money, and the normal operation of the funds can promote the development of textile industry in our country and realize the change from textile big country to textile powerful nation.

\section{Chinese Textile Industry's Position in the National Economy}

\section{The Development Status Of Chinese Textile Industry}

China's textile industry is an important pillar industry in the national economy in China, and it is also the eternal industry in our country that has more than one billion people. At present, our country has the world's largest textile industry system, and its industry chain is of the most complete, from the textile materials production (including natural and chemical fiber) to spinning, weaving, printing, dyeing , clothing and other textile processing, it forms supporting production, and our country has become the biggest producer and exporter in the global textile and clothing industry, which makes a huge contribution to the national economic construction and social development.

The export volume in China's textile industry has increased more than three times from 2000 to 2009, and it accounts for about $15 \%$ of the country's total. The pulling rate about the textile industry export to the national economy has also remained at a stable range. At the same time, the textile industry in China also absorbs most of the labor force, the annual industry average number of workers in China textile industry rose from 4.47 million in 2000 to 10.66 million in 2009, which has played an important role in the national economic development and social stability. 
Tab. 1 The development of China's textile industry

\begin{tabular}{|l|l|l|l|l|}
\hline Year & $\begin{array}{l}\text { Textile } \\
\text { export(Billions } \\
\text { U.S dollars) }\end{array}$ & $\begin{array}{l}\text { The proportion of textile } \\
\text { export in the national total } \\
\text { exports(\%) }\end{array}$ & $\begin{array}{l}\text { The pulling rate about the } \\
\text { textile industry export to } \\
\text { the national economy(\%) }\end{array}$ & $\begin{array}{l}\text { The annual industry } \\
\text { average } \\
\text { number( 10.000) }\end{array}$ \\
\hline 2000 & 530.44 & 21.28 & 0.11 & 447 \\
\hline 2001 & 543.23 & 20.41 & 0.02 & 422 \\
\hline 2002 & 630.18 & 19.36 & 0.10 & 410 \\
\hline 2003 & 804.84 & 18.36 & 0.14 & 788 \\
\hline 2004 & 973.85 & 16.41 & 0.08 & 839 \\
\hline 2005 & 1175.35 & 15.42 & 0.11 & 937 \\
\hline 2006 & 1470.85 & 15.18 & 0.14 & 993 \\
\hline 2007 & 1756.16 & 14,42 & 0.10 & 1040 \\
\hline 2008 & 1896,24 & 13.27 & 0.10 & 1111 \\
\hline 2009 & 1713.32 & 14.26 & -0.13 & 1066 \\
\hline
\end{tabular}

Sources: China National Textile Industry Council, China Statistical Yearbook

\section{The Importance of the Listed Companies' Financing in Textile Industry}

Capital is the first impetus for enterprise to undertake economic activities. It is also very important for the operation and development of enterprise whether the enterprise can obtain the stable source of funding and timely raise the capital that the combination of production factors needs. We should more carefully treat with the, it not only requires that the enterprise management can accurately grasp its own conditions and various financing tools that can be selected, and fully understand many factors and its information influencing the capital market, but need a scientific theory to correctly directed.

\section{The Scale and Structure of the Listed Companies in Textile Industry}

By the end of 2009, there are 98 listed companies of the textile industry in China's A-stock market (excluding the company that its major work has transformed). There are 37 textile listed companies, 26 clothing listed companies, 29 chemical fiber listed companies and 6 textile machinery listed companies. The A-stock market capitalization of listed companies in textile industry is 432.9 billion RMB in 2009, which accounts for $1.5 \%$ of total market value in Shanghai and Shenzhen stock. However, the proportion of total and net assets continues to decline, and the ratio of total assets is decreased from 0.48 percent to 0.41 percent and the net assets is from 1.41 percent to 1.35 percent.

\section{The General Financing Situation of China's Textile Listed Companies}

China's capital market has maintained a momentum of steady growth owing to the economic system reform, which also leads to the development of China's listed companies' financing in capital market.

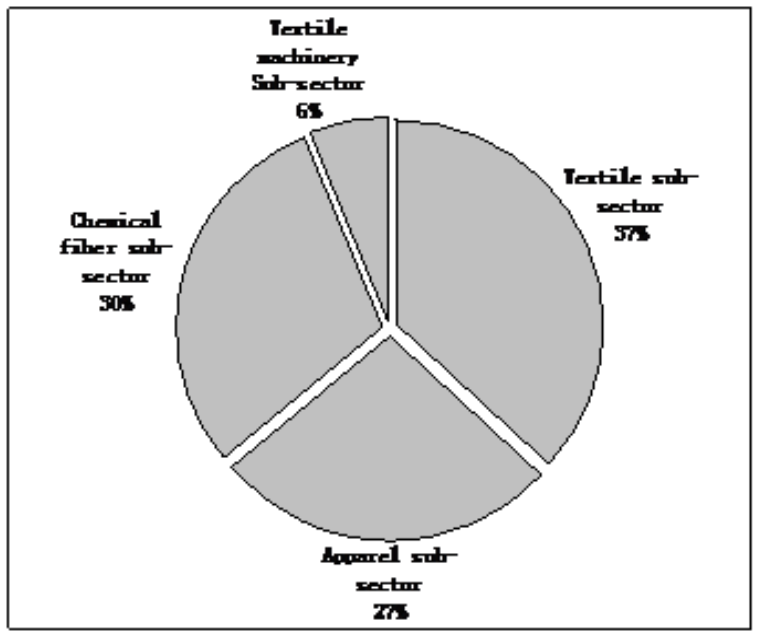

Fig 1 The structure of textile listed companies 


\section{The Status of the Financing Structure of China's Listed Companies}

Financing can be divided into internal financing and external financing according to the sources of funds.

In the theory of capital structure, External financing is the phrase used to describe funds that firms obtain from outside of the firm. It is contrasted to internal financing which consists mainly of profits retained by the firm for investment. There are many kinds of external financing. The two main ones are equity issues, (IPOs or SEOs), but trade credit is also considered external financing as are accounts payable, and taxes owed to the government. External financing is generally thought to be more expensive than internal financing, because the firm often has to pay a transaction cost to obtain it.

In the theory of capital structure, internal financing is the name for a firm using its profits as a source of capital for new investment, rather than distributing them to firm's owners or other investors and obtaining capital elsewhere. It is to be contrasted with external financing which consists of new money from outside of the firm brought in for investment. Internal financing is generally thought to be less expensive for the firm than external financing because the firm does not have to incur transaction costs to obtain it, nor does it have to pay the taxes associated with paying dividends. Many economists debate whether the availability of internal financing is an important determinant of firm investment or not. A related controversy is whether the fact that internal financing is empirically correlated with investment implies firms are credit constrained and therefore depend on internal financing for investment.

External financing takes the dominant position in China's financing market with the proportion of up to 80 percent. There are 50 percent external financing from equity financing which is experiencing an upward trend along with the development of China's stock market. As can be seen from the above data the financing structure of China's listed companies prefer equity financing. The following will mainly analyze the financing situation of textile listed companies from the perspective of equity financing.

\section{The Situation of China's Textile Listed Companies Financing}

The total amount of financing in Shanghai and Shenzhen stock market has reached up to 505.7 billion Yuan which increased 55.08 percent compared with the same period of last year. The amount of financing of textile sector didn't perform stable which showed a downward trend in recent years. The textile sector in stock market has raised 5.12 billion Yuan in 2009, which decreased 6.11 percent compared with the same period of last year. The proportion textile sector's financing takes in Shanghai and Shenzhen stock market had also seen a downward trend from 6.49 percent of 2000 to 1.01 percent of 2009.

Tab.2 The financing situation of China's textile listed companies

\begin{tabular}{|l|l|l|l|l|}
\hline Year & $\begin{array}{c}\text { The financing } \\
\text { amount of textile } \\
\text { listed companies } \\
\text { (Billion Yuan) }\end{array}$ & $\begin{array}{c}\text { The financing amount in } \\
\text { Shanghai and Shenzhen stock } \\
\text { market(Billion Yuan) }\end{array}$ & $\begin{array}{c}\text { The changes of } \\
\text { textile sector } \\
\text { compared with last } \\
\text { year }(\%)\end{array}$ & $\begin{array}{c}\text { The proportion textile } \\
\text { sector takes in Shanghai } \\
\text { and Shenzhen stock } \\
\text { market }(\%)\end{array}$ \\
\hline 2000 & 10.32 & 158.92 & 167.7 & 6.49 \\
\hline 2001 & 6.23 & 109.80 & -39.62 & 5.67 \\
\hline 2002 & 2.48 & 77.69 & -66.75 & 3.19 \\
\hline 2003 & 4.77 & 82.19 & 92.37 & 5.80 \\
\hline 2004 & 3.33 & 84.36 & -30.2 & 3.94 \\
\hline 2005 & 0.28 & 32.45 & -81.64 & 0.86 \\
\hline 2006 & 3.18 & 276.78 & 1042 & 1.15 \\
\hline 2007 & 6.48 & 787.89 & -104 & 0.82 \\
\hline 2008 & 5.45 & 345.75 & -15.9 & 1.58 \\
\hline 2009 & 5.12 & 505.73 & -6.1 & 1.01 \\
\hline
\end{tabular}

Source: WIND, GUOTAI JUNAN SECURITIES

The total amount of financing in Shanghai and Shenzhen stock market has reached up to 505.7 billion Yuan which increased 55.08 percent compared with the same period of last year. The amount of financing of textile sector didn't perform stable which showed a downward trend in recent years. The textile sector 
in stock market has raised 5.12 billion Yuan in 2009, which decreased 6.11 percent compared with the same period of last year. The proportion textile sector's financing takes in Shanghai and Shenzhen stock market had also seen a downward trend from 6.49 percent of 2000 to 1.01 percent of 2009.

Four companies launch IPO in the textile sector of 2009, which are Saturday, Carolina textile, Anna Rich, Pathfinder, raising 2.94 billion Yuan. Five companies implement additional shares (public or private), which are cloud-dimensional shares, Angelo, Langsha shares, Black Peony, Xiake environmental, raising 2.184 billion Yuan. IPO and the amount of refinancing fell $5.56 \%$ and $6.83 \%$ respectively compared to the same period of the last year.

Listed companies in the textile industry in 2009 reached 98 and the cumulative financing from 1992 to 2009 has reached 67.06 billion Yuan, which took 5.67 percent and 2.39 percent respectively compared with the number of listed companies and cumulative financing in the whole Shanghai and Shenzhen stock market. The average amount of financing from textile listed companies amounted to 684 million Yuan, far below the average amount from all listed companies in Shanghai and Shenzhen stock market with the number of 1.62 billion Yuan.

\section{The Operation Situation of China's Textile Listed Companies}

At the end of the third quarter in 2009, 94 listed companies from textile industry obtained 101.17 billion Yuan from sales revenue and gained 607.9 billion Yuan and 459.2 billion Yuan from business profit and net profit, attaining an increase of 14.14 percent and 24.78 percent respectively.

The financial status of 94 textile listed companies has improved significantly compared to the financial status in 2008, of which, the average earnings per share rose to 0.11 Yuan from 0.09 Yuan, realizing an increase of 22.2 percent. Total asset turnover ratio of total asset fell to 0.44 from 0.54 , in the meantime, the operating cash flow per share showed a rising trend, changing from 0.13 Yuan to 0.24 Yuan.

In the case of the four sub-sectors of textile industry, the textile sub-sector listed companies reached the sales revenue of 3.71 trillion Yuan in the first three quarters of 2009 which declined 0.4 percent compared to the same period of last year and gained the total profit of 182.9 billion Yuan and net profit of 12.9 billion Yuan, realizing an increase of 56.35 percent and 57.63 percents respectively. Apparel sub-sector companies reached sales 2.4725 trillion Yuan from the sales revenue in the first three quarters of 2009, declining 2.82 percent compared with the same period of last year. Most apparel listed companies extend their industrial chain from a single sale process to the higher process of marketing to realize a higher profit which also reflects the orientation of the industry's future development. Chemical fiber industry listed realized an income of 3.50 trillion Yuan in the first three quarters of 2009 falling 19.44 percent compared with the same period of last year and gained a profit of 1.14 billion Yuan. Textile machinery listed companies is still in an unsatisfactory performance with the sales revenue of 43.4 billion Yuan in the first three quarters of 2009, declining 31.49 percent compared with the same period of last year.

Tab. 3 The amount of average financing situation of both textile listed companies and all listed companies in Shanghai and Shenzhen stock market from 1992 to 2009

\begin{tabular}{|l|l|l|l|}
\hline Index & $\begin{array}{l}\text { The number of } \\
\text { companies (Jia) }\end{array}$ & $\begin{array}{l}\text { The total amount of } \\
\text { financing(Billion Yuan) }\end{array}$ & $\begin{array}{l}\text { The amount of } \\
\text { average financing } \\
\text { (Billion Yuan) }\end{array}$ \\
\hline Textile listed companies & 98 & 67.06 & 0.68 \\
\hline $\begin{array}{l}\text { All listed companies in Shanghai and } \\
\text { Shenzhen stock market }\end{array}$ & 1728 & 2802.43 & 1.62 \\
\hline $\begin{array}{l}\text { Textile listed companies/ All listed } \\
\text { companies in Shanghai and Shenzhen } \\
\text { stock market }\end{array}$ & 5.67 & 2.39 & 42.17 \\
\hline
\end{tabular}

Source: WIND, GUOTAI JUNAN SECURITIES

\section{The Problems Happened in the Process of Financing of China's Textile Listed Companies}

Stock market has become an important financing source for China's textile listed companies. China's textile listed companies has achieved great quantity of impressive achievements, but they also encountered numerous problems in the process of listed companies' development. 
As can been see from the above date analysis about the equity financing situation of Chinese textile listed companies, there exists some problems, such as low stock share price and the slow-speed of investment extension which lead to a declining market share for textile listed companies. The following are some other problems faced by China's textile listed companies.

\section{The Low Proportion of internal Financing For textile Listed Companies}

The main source of internal financing comes from the company's profitability. A large number of textile listed companies lack effective internal financing mechanisms. They transferred the most profits of the companies to shareholders, management staff and employees instead of expanding the financing which result in the low proportion of internal financing of China's textile companies.

\section{Large Proportion Is Occupied by State-owned Shares in Textile Listed Companies}

Amount most of the textile listed companies state-owned shares account for a large percentage in the whole companies' shares. So, issuing the high-priced shares doesn't affect the control power for the companies which affect the companies' vitality.

Tab.4 The key financial indicators of 94 listed textile companies

\begin{tabular}{|l|l|l|l|l|l|l|}
\hline & Time & $\begin{array}{l}\text { Textile } \\
\text { sub-sector }\end{array}$ & $\begin{array}{l}\text { Apparel } \\
\text { sub-sector }\end{array}$ & $\begin{array}{l}\text { Chemical fiber } \\
\text { sub-sector }\end{array}$ & $\begin{array}{l}\text { Textile } \\
\text { machinery } \\
\text { Sub-sector }\end{array}$ & $\begin{array}{l}\text { 94 listed textile } \\
\text { companies }\end{array}$ \\
\hline $\begin{array}{l}\text { The turnover } \\
\text { rate of total } \\
\text { asset } \%)\end{array}$ & $\begin{array}{l}\mathrm{Q} 3, \\
2009\end{array}$ & 0.49 & 0.35 & 0,50 & 0.32 & 0.44 \\
\cline { 2 - 7 } & $\begin{array}{l}\mathrm{Q} 3, \\
2008\end{array}$ & 0.54 & 0.41 & 0.67 & 0.48 & 0.54 \\
\hline $\begin{array}{l}\text { Earnings per } \\
\text { share } \\
\text { (Yuan) }\end{array}$ & $\begin{array}{l}\mathrm{Q} 3, \\
2009\end{array}$ & 0.08 & 0.32 & 0.06 & -0.15 & 0.11 \\
\cline { 2 - 8 } & $\begin{array}{l}\mathrm{Q} 3, \\
2008\end{array}$ & 0.05 & 0.37 & -0.03 & 0.00 & 0.09 \\
\hline $\begin{array}{l}\text { Operating cash } \\
\text { flow per share } \\
\text { (Yuan) }\end{array}$ & $\begin{array}{l}\mathrm{Q} 3, \\
2009\end{array}$ & 0.20 & 0.45 & 0.18 & 0.05 & 0.24 \\
\cline { 2 - 8 } & $\begin{array}{l}\mathrm{Q} 3, \\
2008\end{array}$ & 0.20 & 0.13 & 0.09 & -0.04 & 0.13 \\
\hline
\end{tabular}

\section{Lack of a Mature Bond Financing Market}

The development of China's stock market is lagging behind compared with the development of China's stock market. In addition, there are strict regulations for issuing bonds of listed companies. The regulations and the high entry threshold limit the bond financing for textile listed companies which results in a small-scale bond financing.

All the financing problems in textile listed companies are seriously restricting the optimization of financing structure of China's listed companies, resulting in the low capacity use efficiency and low self-accumulation capacity.

\section{Proposals on the Financing Healthy Development of China's Textile Listed Companies}

China's textile industry played an important role in national economy development and the improvement of people's living standards. The textile industry will continue to develop rapidly with the growing domestic and international demand and sufficient funds can guarantee its smooth development. The following countermeasures are raised based on the above analysis about China's textile companies.

\section{Integrate with International Capital Market}

Make full use of both domestic and overseas capital markets, realizing Chinese textile industry companies listed overseas. Limited capacity of the domestic capital market prevents the textile listed companies' development. International securities markets are more mature, and the market capacity large enough to meet the needs of large-scale financing. So it is a wise choice to raise capital from international stock market. 


\section{Improve the Stock Liquidity of the textile Listed Companies by Reducing State-owned Shares}

Reducing the state-owned shares can increase the proportion of tradable shares which would enable the stock price reflect a company's true operating performance and market competition degree. In this way the manager's operating results could connect with the stock price which will link the manager's personal interests with the interests of the whole company. So, the managers will work more hard to gain personal profit and in the meantime improve the operating efficiency of the whole company.

\section{Acknowledgement}

This article is sponsored by Shandong Provincial Science and Technology Development Planning project(2014GGH213001) " Study on the early warning mechanism of agricultural industry damage of Shandong province from the perspective of global value chain" hosted by Wang Peizhi; Shandong Provincial Natural Science Foundation project(ZR2013GM013) "Research on agricultural products trade's marginal measures and upgrading route of Shandong Province" hosted by Wang Peizhi; Shandong Provincial Academy of Social Sciences project(14AWTJ01-15) " Research on early warning system of financial internationalization development in Shandong Province " hosted by Wang Peizhi; Shandong Education Department's Project (sdyy11201) "Research on Innovation of Bilingual Teaching of Graduates in International Business, Shandong University of Finance and Economics" hosted by Liu Xinying; Project (jy201212 )"Research on Combining Chinese Graduates with Foreign Students in Teaching International Economics and Trade in English" hosted by Liu Xinying; Shandong science and Technology Department Project(2014RKB019A6) "Research on agricultural industry security of Shandong province from the perspective of open market" hosted by Liu Xinying.

\section{References}

[1] Wang Jie, Yang Wu. New China's economic geography [M]. Bei Jing: The Press of Central University for Nationalities , 2010.04.

[2] Chen Qiwei. Corporate Finance [M]. Bei Jing: China Financial Publishing House, 2003.

[3] Nina Meng. The status and analysis of China textile industry [D]. Business Economics, 2009.

[4] 2010 China Textile Industry Development Report [M]. Bei Jing: China Textile Press, 2010, 05.

[5] Li Huimin. Research on optimizing financing structure of China listed companies [J]. Financial Times, 2009 .

[6] Fama EF and KP French.Financing decisions: who issues stock? [J]. Joumal of Financial Economics,2005. 